\title{
Web Marketing of Islamic Banks in Malaysia Can Website Help in Reducing Negative Perception about Islamic Banks?
}

\author{
Tahreem Noor Khan ${ }^{1}$ \\ ${ }^{1}$ Al Yamamah University, Saudi Arabia \\ Correspondence: Tahreem Noor Khan, Al Yamamah University, Saudi Arabia. E-mail: \\ tahrimnoor@hotmail.com
}

Received: October 5, 2014

Accepted: November 6, 2014 Online Published: January 26, 2015

doi:10.5539/ijms.v7n1p146

URL: http://dx.doi.org/10.5539/ijms.v7n1p146

\begin{abstract}
Since the development of Islamic banking, negative concerns prevail because of low customer awareness and understanding of Islamic banking and its financing methods. Trust and credibility factor for Islamic products are low. Operational concerns exist specifically about staff and scholars. A perennial challenge facing all Islamic financial institutions is how to communicate with customers in a way that will affects their behaviours or attitudes.

For developing relationship with consumers, it is imperative for Islamic banks to remove all negative concerns and doubts by developing educative and effective marketing strategy utilizing all their contact channels. Specifically, in reaching to the consumers effectively, Websites can be utilised in giving appropriate, sufficient, and relevant information. The distinctive aspect of this paper is that it analyses the Islamic bank websites which were evaluated against criteria developed through a literature review of existing Islamic banking challenges. Research questions were developed to investigate the issue. This research is Qualitative and descriptive in nature, as two Islamic banks websites of Malaysia were accessed in 2010 and 2014 in order to understand the differences and similarities with regard to website structures, content, information, colour theme and target audiences of marketed web products. By investigating these factors descriptively, this research provides practical suggestions to design effective webpages or promotional messages to educate and inform customers of the distinction between Islamic banking products and services, and those offered by conventional banks. Moreover, along with serving marketing purposes, this study also believes that Islamic banks can use their websites for recruiting, informing consumers about their social activities, and the Sharî ah board.
\end{abstract}

Keywords: Islamic banking, Malaysia, marketing, website

\section{Introduction}

Most financial institutions describe their bank activities and products through Newspaper, Television, and Brochures. Along with all those marketing communication channel websites are the most effective source of communicating and providing information to consumers. Most of the web features like new product information, online banking and customer service are implemented on main webpage, and the information on the websites can be graphically attractive and interactive, and it can be updated on a continual basis (Jasimuddin, 2001).

Therefore, when existing or potential customers wanted to enquire more about Islamic banking products, they instantly search on the websites. Their queries and concerns can be resolved if sufficient and relevent information can found at bank webpage. However if they cannot find any specific information for example product structure, charges, profit rate at bank webpage, it will impact negatively on customers. Realizing this fact it is very important for Islamic banks to design their website and advertisements by understanding consumer needs and requirements.

In the existing literature, good number of article has been written on the impact of internet banking service (Rotchanakitumnuai \& Speece, 2003; Wang et al., 2003; Jun \& Cai, 2001), but there is not any specific study found on evaluating, measuring, observing the effectiveness of Islamic web-marketing in reducing the doubts and misconceptions. 
Therefore, this paper steps forward to begin filling that gap in the literature. The scope of this research is to investigate the key issues of Islamic banks discussed in literature review (Used Arabic names for credibility and reliability, Website focused too much on graphics and serving advertising purposes, Unclear Marketing, Target Segment not clear) and then evaluate the degree of usefulness of web advertising messages of two full-fledged Islamic banks in Malaysia. Bank Islam and Bank Muamlat are selected because they are holding the largest Islamic assets in Malaysia. To explore the factors this research has adopted qualitative and descriptive research approach.

\section{Literature Review}

This paper focuses on Islamic banks in particular because they are growing rapidly by adopting different techniques. In the last few years, some small Islamic banks merged with large Islamic banks and most of the conventional financial brands started to offer Islamic banking products to attract consumers' attention. However, as this industry progresses, Islamic banks face some challenges, criticism and stereotypical attitudes about their operational authenticity, product charges, management inefficiency and marketing gimmicks.

\subsection{Used Arabic Names for Credibility and Reliability}

Most Islamic banks' marketing messages did not inform their potential customers sufficiently clearly about the factors that make them religiously and ethically correct (Wahib, 2007). ElGamal (2007) and Haron (1994) raised the concern that Islamic banks repackaged conventional products by modifying non-Sharîah aspects and used Arabic names for credibility and reliability (Saeed, 1996; Tahir, 2003). No additional explanation is provided to the customers, and the contract finishes simply by signing paperwork, which usually contains only one sentence about the nature of the Sharîah principle governing the facility (Ahmad, 1994). Kahf (2002) and Wilson (2005) also drew attention to the fact that the publicity materials and annual reports of Islamic banks do not tell the reader more than that "the bank's operations are in Sharīah compliance". Wilson (2005) also stressed the fact that Islamic bank websites should give more explanation about how riba $\bar{a}$ is equated with interest and usury, and should elaborate on the principles used by the banks for financing instruments.

Furthermore, a survey result of Bley and Kuehn (2004) showed that in the UAE Muslim male students and students with a high level of Arabic fluency perceived Islamic finance more favourably than conventional finance. However, the use of Arabic terminologies such as Mushārakah, Muḍārabah, Ijārah and Istișna for Islamic finance products seems difficult for the non-Arabic and non-religious consumers to understand (Al Zaabi, 2007). For that reason, non-Muslim consumers thought that the concept of Islamic finance appealed only to Muslims (Bley \& Kuehn, 2004). These findings suggest that education can assist in making people more knowledgeable about the products offered.

\subsection{Website Focused Too Much on Graphics and Serving Advertising Purposes}

There was also an indication in the literature that Islamic banks' websites focused too much on graphics and serving advertising purposes, rather than providing technical support to customers for customer service and online banking (De et al., 2004; Wilson, 2005). As in previous studies it indicate that customers were reluctant to adopt Internet banking due to a lack of experience, lack of prompt service, privacy and security issues (Rotchanakitumnuai \& Speece, 2003; Wang et al., 2003; Jun \& Cai, 2001). Amin (2007) investigated consumer acceptance for Internet banking from the perspective of Islamic banking institutions. His conclusion suggested that Islamic banks should organise training courses about privacy and security issues. This would help to develop confidence and credibility about Internet banking among existing customers.

\subsection{Unclear Marketing}

With reference to advertisements, Islamic scholars pointed out that credit card advertisement campaigns at Islamic banks are misleading and exploiting their customers (Obaidullah, 2005; Asharq AlAwsat, 2008). Some customers reported that their attraction to these banks' credit cards was mainly due to the Shari'ah compliance assurance and false promises of advertising campaigns; the cards purported to be easy to apply for and repay, but additional monthly charges accumulated over the prolonged duration for which customers have to bear their debts (Asharq AlAwsat, 2008). Haque et al. (2010) also observed that incentives were common during marketing campaigns. These marketing campaigns tend to confuse their customers with catchy titles offering a higher return on deposit, while the banks which offer very low rates do not advertise their deposits widely (Ali, 2000).

While reviewing the literature, it was also observed that most of the Islamic bank marketing campaigns became more active during the Islamic or religious seasons like Ramadan and Hajj, because consumers spend more during these seasons (Arabian Business, 2010). 
In the literature, the practices discussed above are considered banking marketing tricks that have little to do with religion and more to do with profits. Islamic banks' advertisements should not urge customers to use a halāl debit card to win a large amount or to enter a lucky draw that enables them to perform Hajj or Umrah, because this looks very similar to gambling (Hussain, 2007).

Some of the scholars in Malaysia believed that the profit motive should be taken into consideration when advertising and marketing Islamic products (Tanjung, 2005). However, the literature revealed that a marketing approach based only on profit factor is not acceptable as a means of attracting and establishing relationships with Muslims (Haron, 1994). Haron and Ahmad (2000) also suggested that the Islamic banks should not emphasise the profit factor in their marketing. The bank should emphasise instead that the return, whether it is profit or loss, comes from Allah.

Considering the above analysis, such incentives as the chance to win a prize, or receiving a gift with a certain number of proofs of purchase, should be avoided when advertising Islamic products. Furthermore, over-emphasis on incentives can jeopardise an Islamic brand. Sharīah scholars also claim that such rewards, given on a regular basis without sharing the risk of a partnership, constitute a form of $r i b \bar{a}$ and are very similar to conventional banking practices (Zaharuddin, 2006).

\subsection{Target Segment Not Clear}

The literature also indicated the fact that Islamic banks' marketing campaigns were targeting those already targeted by conventional banks (Ahmed \& Rehman, 2010) suggested that bankers could attract more customers by launching effective marketing campaigns according to demographics to enhance awareness about their products and services, and factors such as focusing on emotional product differentiation and triggering customer needs could be used as advertising strategies for Islamic banks (Jalees, 2005).

The survey conducted by Hamid and Nordin (2001), Ahmad et al. (2008) and Maran et al. (2010) also noticed that Islamic bank product marketing was not sufficiently wide-ranging, as they were targeting religious customers only. Due to a lack of understanding and information, some consumers did not choose Islamic banking products and some thought that Islamic banking was only for Muslims (Maran et al., 2010). Respondents of their study further indicated the possibility of establishing a relationship with Islamic banks if they had a complete understanding of their operations. Therefore, Ahmed et al. (2008) strongly suggested that banks should build different marketing strategy for those groups who have not had any formal Islamic education, as they cannot understand the Islamic elements of the banking products.

\section{Research Method}

This research is Qualitative in nature as from existing literature, the research questions are developed. And to evaluate those issues of marketing Islamic bank web content was analyzed. Due to spacing and word limitation, only the information of two full-fledged Islamic banks websites 1) Bank Muamalat and 2) Bank Islam are descriptively analysed. Bank Islam is the largest bank commenced its operations in July 1983. Bank Muamalat is second largest Islamic bank in Malaysia and it was established on 1999.

This research observed the same variables over specific periods of time. The Islamic banks websites were accessed during the period between 1 May 2010 - 10 May 2010 and 1 July 2014 -10 July 2014. Different year and months are chosen to observe the marketing pattern over period of time. Due to the changing nature of website content, it was decided to limit the time in which the relevant information was captured.

Based on above discussion, it was found that there is a gap in the literature in establishing relationship with customers using web contact channel. Therefore this research make an attempt to understand the issues which Islamic banks were facing from literature review and linking it with the role of website in removing stereotypical attitude or concerns.

This research will answer following questions:

Q1- What is the theme of marketing: emotional appeal (Focus on Attractive rates or gifts) or rational appeal (justification from Islamic perspective)

Q2- Are Islamic bank websites prefer more visual appealing aspect (Colour of website) animation and graphic which make it difficult to navigate?

Q3- Are they targeting specific segment? What are the main products which are more focused on websites of Islamic bank?

Q4- Is the usage of Arabic terminologies more in Islamic bank website? 


\section{Findings}

\subsection{Webpage Product Advertisements of Islamic Banks in Malaysia}

1) Bank Islam Malaysia - The Webpage colour theme is white and red. The basic graphic was there on webpage. The main advertisement of Bank Islam Malaysia in 2010 and in 2014 was for its Islam Visa Card. In 2010, Bank Islam advertised attractively with incentives (using a contest offering customers who performed transactions of RM50.00 the chance to win a grand prize of a 52 inch TV and other gifts). The daily prize was an exclusive Adidas Football Pack consisting of a cap, bag, tumbler, football and towel (Figure 1).

Along with Visa Master card was also advertised where customer can win a Grand Prize - Hajj Pilgrimage package based on the highest transaction. The Malay language was used in the advertisement, which had as its caption 'Reply to the Holy Land - Performing the $5^{\text {th }}$ pillar of Islam is likely to become a reality with Master Card, your Islamic Bank'. The other monthly prizes were an Azan Clock, a digital Qur'ān and a pen. For non-Muslims, the grand prize (a Hajj package) would be converted to a holiday voucher worth RM25,000. The advertisement mainly focused on spending as much as possible in order to win the grand prize. Information about the product structure was missing for both above. Frequently Asked Questions cannot be found on webpage.

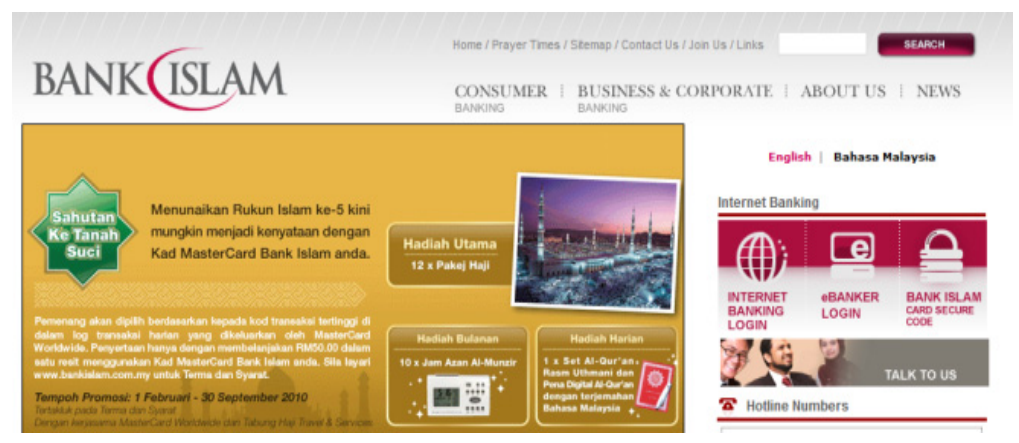

Figure 1. Bank Islam -Visa Master card (2010)

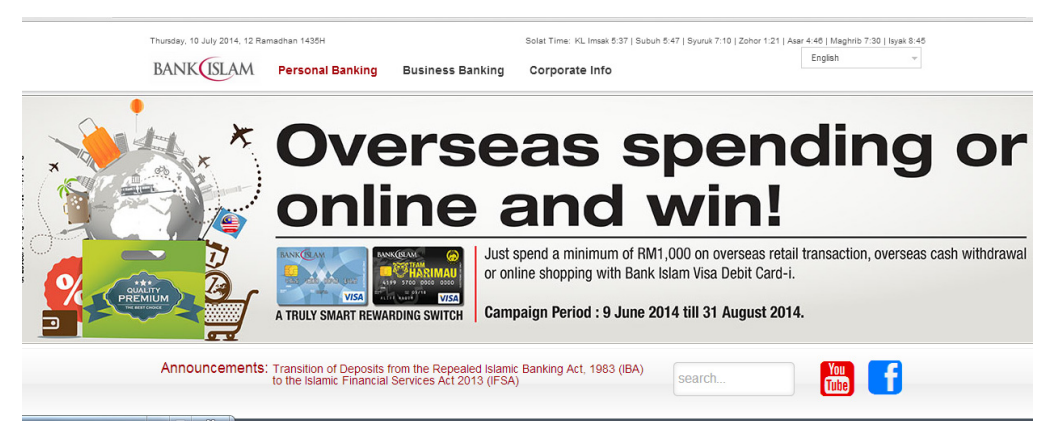

Figure 2. Bank Islam -Visa Debit Card (2014)

In 2014, the website of Bank Islam advertised a Visa 'Debit Card-i Spending Campaign'. Card member need to spent a cumulative amount of RM3,000 on retail transactions in United Kingdom or RM1,500 online at local online merchant (Figure 2). First Prize Travel Voucher worth RM10,000, Second Prize Travel Voucher worth RM8,000, Third Prize Travel Voucher worth RM5,000.

Second web advertisement of BankIslam is Islamic debit card where the focus of Promotion is "Get $20 \%$ Off On Normal Price Menu at Burger King” (Figure 3). 


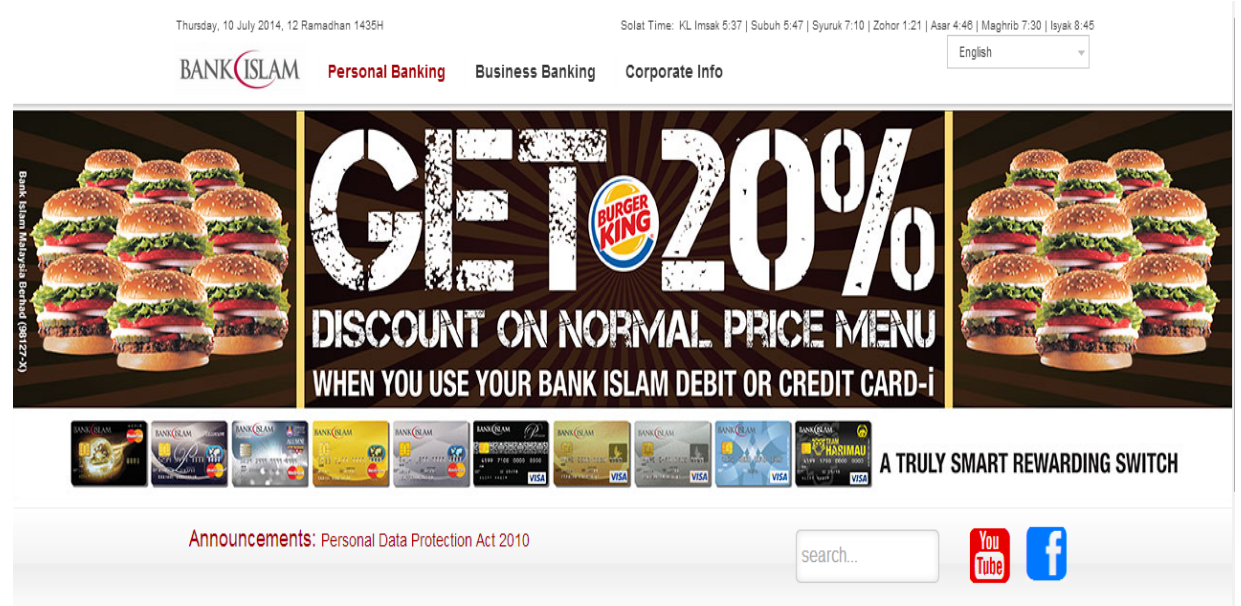

Figure 3. BankIslam is Islamic debit card (2014)

Bank Islam third advertisement focusing on Personal Financing BMW Campaign, which can be apply in three easy step. 1) Visit Bank Islam and apply for personal financing, 2) accept and sign a letter, 3) stand a chance to win BMW.

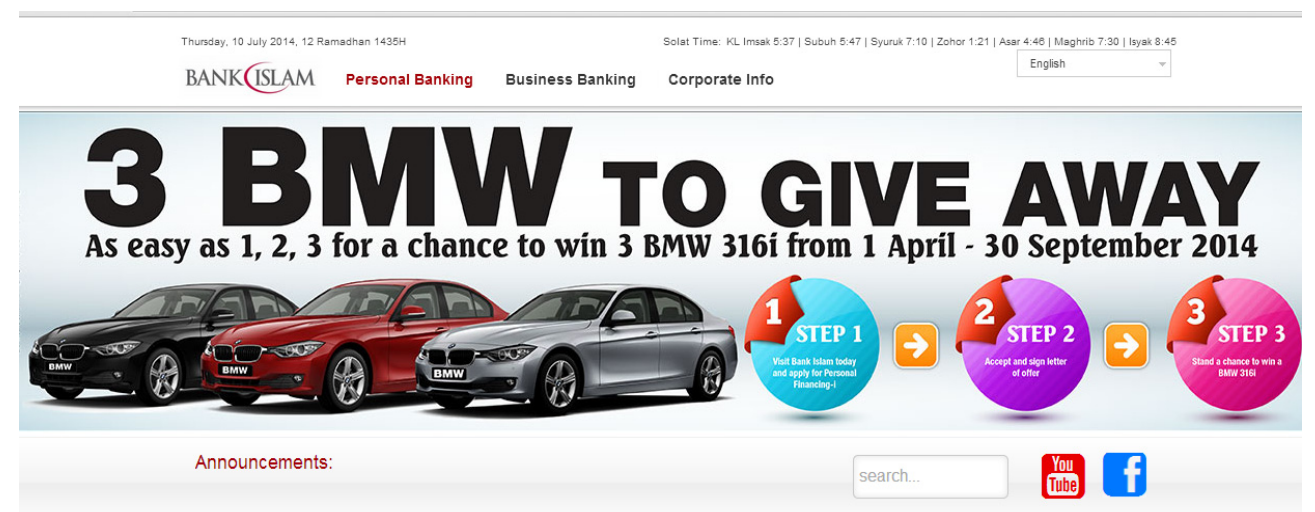

Figure 4. Personal financing BMW campaign (2014)

2) Bank Muamalat- second largest Islamic bank was established on 1999. The Webpage colour is white and blue. Basic flash graphic found where products were advertised.

In 2010- The webpage of Bank Muamalat advertised three products:

- Home financing (Bay Bithaman äjil)

- Children's Muḍārabah Saving Accounts (for 12 ages and above, minimum account balance RM 1000, high profit ratio on higher account balance)

- Zakāt service uses references from the Qur'ān and Haḍth.

Quranic reference: O you who believe! Verily, there are many of the rabbis and the monks who devour the wealth of mankind in falsehood, and hinder (them) from the way of Allah. And those who hoard up gold and silver, and spend it not in the Way of Allah - announce unto them a painful torment." (Qur'ān 9:34).

Hadith reference: The Prophet said, "Islam has been built on five pillars: testifying that there is no god but Allah and that Muhammad is the Messenger of Allah, performing the prayers, paying the Zakāt, making the pilgrimage to the House (Hajj), and fasting in Ramadan." (Bukhari, Muslim).

- Used Arabic mode of finance, but no explanation was provided. 


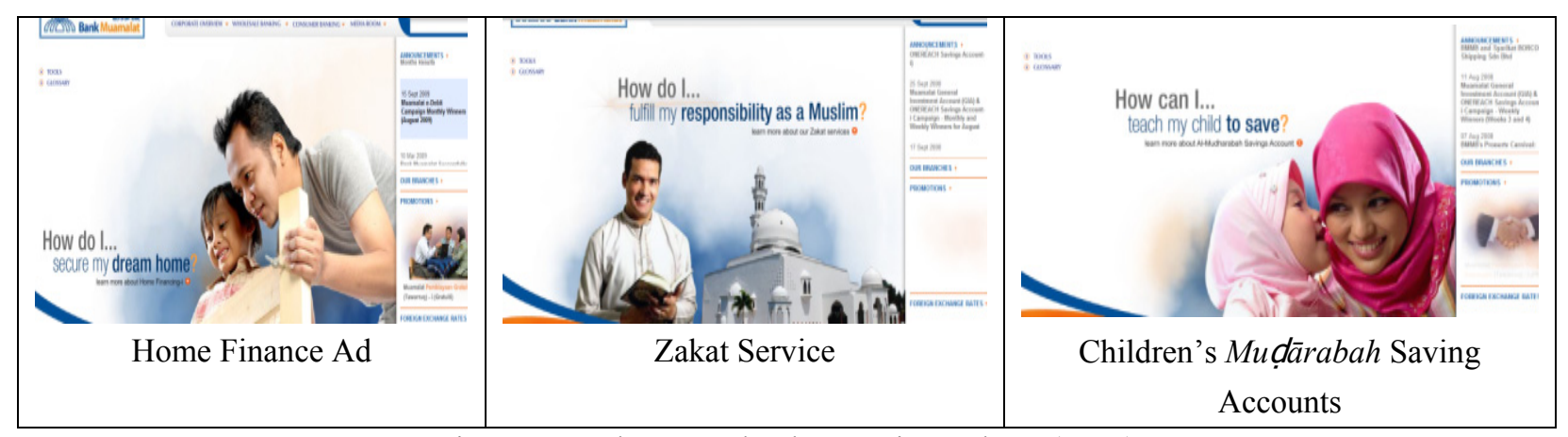

Figure 5. Bank Muamalat three main products (2010)

In 2014- The webpage of Bank Muamalat advertised two main ad:

1- 'Ar Rahnu': the explanation about product was in Malay. Furthermore in the ad red label ' With Attractive package' is stated but not more detail is provided. The eligibility of this product is that the customer can get loan of up to $80 \%$ of the current value of the jewellery or Rs $75,000.00$ per customer (RM25K for each Letter of Charges). The minimum loan is 250.00 for each of the pawned.

2- Car Takaful: This specific ad focus on five elements: 1) 24 hours road assitace, 2) compensation for the lost of use, 3) E cover note, 4) fast claim approval, 5) auto policy remider through SMS. No further information is provided.

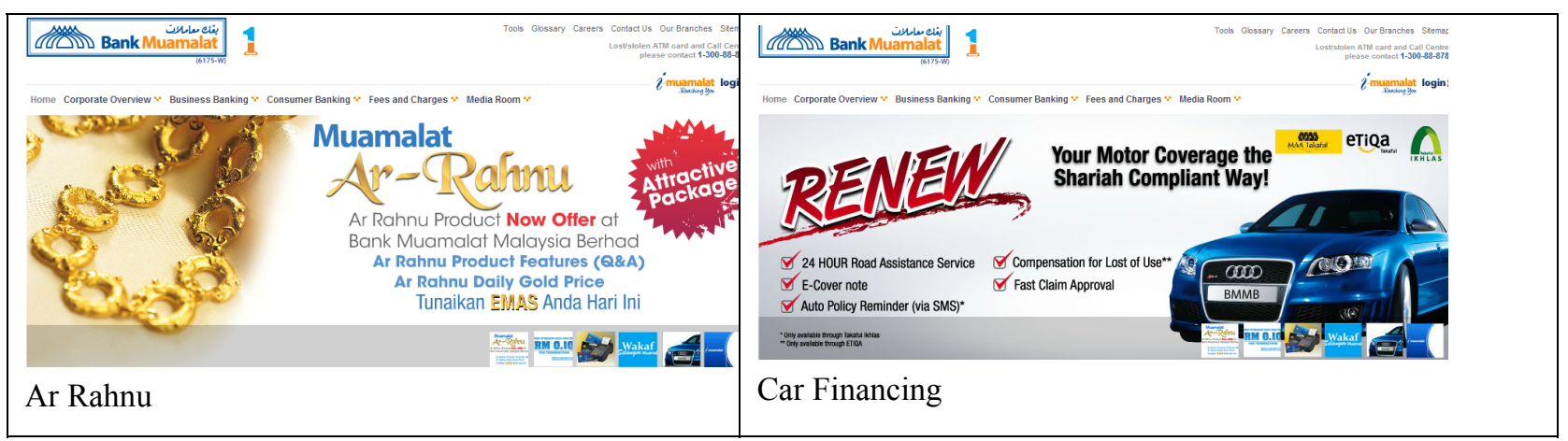

Figure 6. Bank Muamlat website ads (2014)

\section{Discussion}

\subsection{Theme of Marketing: Emotional Appeal (Focus on Attractive Rates or Gifts)}

While evaluating websites, it was observed that most of the Islamic bank websites advertising Visa cards stress rewards like discounts, reward points, and prizes; however, Sharîah-related information was missing from their advertisements. Bank Muamlat featured Qur'anic or Hadith references but no one used Islamic expressions on their webpages. However, the literature believes that the use of selected Qur'anic injunctions and words like 'Bismillah' (in the name of God) or 'Assalam Alaikum' (peace be upon you) can enhance the mood of marketing communications (Ahasan-ul-Haque et al., 2010). Based on the above discussion, my findings concur with the findings in the literature that the ethical and religious dimension should be the central part of Islamic financial institutions' marketing campaigns (Warde, 2000). If no effort will be made to explain the characteristics of Islamic finance, then the perception will prevail that Islamic banks pay interest in the name of profit. Therefore, it was considered important to raise the concern that banks should inform customers about Sharîah compliance rather than urging them to spend more in order to win incentives or prizes.

\subsection{Islamic Bank Websites Visual Appeal (Colour of Website) Animation and Graphic}

No heavy graphic was found on the website. White and Blue (Bank Muamlat) and White and Maroon (BankIslam) colours are used. 


\subsection{Target Specific Segment and Main Products Which Are More Focused on Websites of Islamic Bank}

It is found that Visa, Master, Debit and Car financing are more advertised. However, a grave concern arising from evaluating Islamic bank websites was that none of the largest Islamic bank websites focus on products for low-rate mortgages and credit cards, low-earning consumers, education financing for students, females and expatriates. Together with the literature findings, this study also considered that marketing messages can be delivered more powerfully if campaigns are directed at specific groups (e.g., females, expatriates, conventional bank users, specific age groups), as each group has different needs (Ahmad et al., 2010; Ahmed, 2008; Mokhlis, 2009; Maran et al., 2010).

\subsection{Information about Product or Islamic Bank Activities}

Islamic bank websites can upload videos to explain differences between conventional credit cards and Islamic credit cards; features of Islamic classic, gold and silver cards; annual and subscription fees; fees for cash withdrawal; purchases in foreign currency; late payment fees; payment pricing/administration costs; and Sharīah structure of the product. Studies have revealed that customers would be disappointed to find that Islamic bank product charges are expensive compared to conventional products (Metawa \& AlMossawi, 1998; Zaman \& Movassaghi, 2002; Anwar, 2001; Rosely 2003).

Underpinning all of the above discussion, it was found that Islamic bank websites did not provide enough information about Sharîah products. Indeed, Islamic banks in Malaysia focus on winning prizes and offering incentives in their web advertisements. Also, it was noticed that Islamic banks have targeted specific products on their websites; for instance, personal financing and credit/debit/visa cards were advertised. Based on evaluating web marketing messages, it is evident that Islamic banks can emphasise the religious aspect of their business as well as specific factors that distinguish Islamic financial institutions from other financial services.

Introductory educational campaigns need to be prepared in order to educate consumers about the differences between Islamic and conventional values, because Islamic banks cannot run their businesses successfully if people do not understand the main objectives of their banking system (Hussain, 2007). The findings of this research believe that awareness among consumers can decrease the negative or sceptical attitudes about Islamic banking products, which is discussed heavily in literature review. The significance of this is that if the negative perceptions are not altered, then doubtful and sceptical consumers may reject the overall marketing claims of Islamic banks and avoid choosing Islamic financial products because they do not trust the mechanism of the system. Therefore, Islamic banks can use their websites to connect with and educate consumers about the cost and structure of Islamic banking products.

Further interactive and innovative initiatives could include webpages with voice recognition; the ability to call a personal bank employee via a video connection; uploading videos about Islamic banking products. These initiatives will help customers to familiarise themselves with the Islamic bank's products range and Internet banking services.

Other uses of websites include informing customers about the Sharîah board and building an effective staff recruitment system.

While evaluating the websites, it was further noted that Islamic bank websites do not make any effort to collect information about customers, and therefore do not provide any special services. Islamic banks can further improve their websites by measuring the number of consumers visiting the site, noting the most viewed page that contains a product or service advertisement, and evaluating the nature of complaints registered by customers (website technicality, product issues, card issues, Internet banking).

An additional suggestion in this regard is to collect customer responses through forms/feedback/surveys/polls on a regular basis in order to solve customer service issues. To give accurate answers while reducing response times, websites can provide an email address that customers can contact directly about their concerns.

\section{Suggestions}

Based on the above concerns, this research believes that Islamic banks can have balance approach in offering subjective and objective factors of marketing. To provide balance approach, Islamic banks should review and evaluate the effectiveness of marketing campaigns, web-services and web recruitment policy by answering a few questions:

- Does the advertisement only engage customers emotionally or does it provide information about products from a Sharīah perspective?

- Do Islamic banks have system to track the data regarding who is using Islamic bank websites? (gender, age 
group, users/non-users of Internet banking, local/expatriate)

- Which products on the websites are most/least frequently visited?

- What are the rates of successful and unsuccessful requests online?

- How well does the marketing on Islamic bank websites convey their message compared to traditional marketing media? How positively do customers respond to web-marketing?

- How effective are the various different Islamic bank web-marketing schemes or strategies in raising awareness, promoting, persuading and putting new ideas into the consumer's mind?

- Can short-term Islamic products marketing during Islamic season (Ramadan, Hajj) help to build long-term relationships with customers?

It is important to acknowledge the limitations of this research. Due to limited spacing and word limit only the web advertisements of full-fledged Islamic banks have been studied. Therefore, it would be useful to explore the subjective and objective elements of web advertisements produced by conventional banks offering Islamic products. Furthermore, adding the element of customer attitudes toward Islamic web marketing to future studies would provide scope to refine Islamic banking web marketing strategies. Due to the lack of research in this topic, the researcher set some factors to analyse the web marketing of Islamic banks, and the outcome of this study provides a basis for further investigation in this area.

\section{References}

Abdel Khaleq, A. (2004). Offering Islamic Funds in the US and Europe. Texas Transactional law Quarterly, 8(3), 6-8.

Abdullah, S. (2009). Financial Crisis: Should Islamic Banks Share Equal Responsibility. Arab News [Saudi Arabia] April 27, 2009.

Ahasan, H. (2010). Islamic Banking in Malaysia: A Study of Attitudinal Differences of Malaysian Customers. European Journal of Economics, Finance and Administrative Sciences, $18,816$. http://dx.doi.org/10.1108/17590831011026240

Ahasan, H., Ahmed, K., \& Jahan, S. I. (2010). Sharīah Observation Advertising Practices of Bank Muamlat in Malaysia. Journal of Islamic Marketing, 1(1), 70-77.

Ahmad, K. (1994). Islamic Approach to Development: Some Policy Implications. Islamabad, Institute of Policy Studies.

Ahmad, W., Rahman, A., Nor, A. A., \& Azizi, C. S. (2008). Religiosity and Banking Selection Criteria among Malays in Lembah Klang. Sharī á Sharīah Journal, 16(2), 279-304.

Ahmed, A. (1995). The Evolution of Islamic Banking in Encyclopedia of Islamic Banking, London: Institute of Islamic Banking and Insurance.

Al Zaabi, O. (2007). Measuring the Perceived Service Quality: An Empirical Study of Islamic Banks in the UAE. IIUM International Conference on Islamic Banking, Kuala Lumpur, April 23-25.

Ali, S. (2000). Philosophy of Islamic Banking. Finance \& Market Magazine, October 2, 2000.

AlSomali, A., Roya, G., \& Clegg, B. (2008). Internet Banking Acceptance in the Context of Developing Countries. Research Publication, Serial. 0803. Birmingham, Aston Business School.

Amin, H. (2007). An Empirical Investigation on Consumer Acceptance of Internet Banking in an Islamic Bank. Labuan School of International Business and Finance, 5.

Amin, H. (2007). Islamic Automobile Financing: Do Demographics Matter?. Labuan School of International Business and Finance, 8, 68-81.

Anwar, M. (2000). Islamicity of Banking and Modes of Islamic Banking. Report, International Islamic University, Malaysia, October 31.

Arabian Business. (2010). Banks in Ramadan Marketing Push to Spur Growth. Retrieved from http://www.arabianbusiness.com/banks-in-ramadan-marketing-push-spur-growth-346085.html

Asharq AlAwsat. (2008). The Islamic Credit Card Controversy. [Saudi Arabia] August 27.

Bacha, O. I. (2006). Dual Banking Systems \& Interest Rate Risk for Islamic Banks. Bimaquest, 6(2), 47-63.

Bank Islam (Malaysia). Retrieved from http://www.bankislam.com.my/ 
Bank Muamalat (Malaysia). Retrieved from http://www.muamalat.com.my/

Bley, J., \& Kermit, K. (2004). Conventional Versus Islamic Finance: Student Knowledge and Perception in the United Arab Emirates. International Journal of Islamic Financial Services, 5(4).

Croonenberg, H., \& Von, P. (2006). Islamic Finance: What Leaders Do Differently. Brief Paper no. 8. A.T.KEARNEY. Retrieved from atkearney.de/content/misc/wrapper.php/id/49615/area/bankenvers

De, K., Shakeel, A., \& Somashekar, M. (2004). Impediments to Technology Transfer and Technology Absorption in the UAE. 13th Conference of International Association for Management of Technology (IAMOT), Washington.

Dusuki, A. W., \& Abdullah, N. I. (2003). Maqasid AlShari ah, Maslahah, and Corporate Social Responsibility. American Journal of Islamic Social Sciences, 24(1), 24-45.

Dusuki, A. W., \& Abdullah, N. I. (2007). Why do Malaysian Customers Patronize Islamic Banks?. International Journal of Bank Marketing, 25(3), 142-160. http://dx.doi.org/10.1108/02652320710739850

ElGamal, M. (2000). The Economics of 21st Century Islamic Jurisprudence. Retrieved from http://www.ruf.rice.edu/ elgamal/files/jurists.pdf

Furnell, S., \& Titis, K. (1999). Security Implications of Electronic Commerce: A Survey of Consumers and Business. Internet Research: Electronic Networking Applications and Policy, 9(5), 372-382. http://dx.doi.org/10.1108/10662249910297778

Hamid, A. H., \& Nordin, N. A. (2001). A Study on Islamic Banking Education and Strategy for the New Millennium - Malaysian Experience. International Journal of Islamic Financial Services, 2(4).

Haron, S., Ahmad, N., \& Planisek, S. (1994). Bank Patronage Factors of Muslim and Non-Muslim Customers. International Journal of Bank Marketing, 12(1), 32-40. http://dx.doi.org/10.1108/02652329410049599

Howcroft, B., Robert, H., \& Paul, H. (2002). Consumer Attitude and the Usage and Adoption of Home-Banking in the United Kingdom. International Journal of Bank Marketing, 20, 111-121. http://dx.doi.org/10.1108/02652320210424205

Hussain, S. (2007). Profit in the Name of Religion. The News [Pakistan] July 7.

Iqbal, M., \& Molyneux, I. (2005). Thirty Years of Islamic Banking: History, Performance, and Prospects, Houndmills, Palgrave Macmillan.

Jabnoun, N., \& Khalifa, A. (2005). A Customized Measure of Service Quality in the UAE. Managing Service Quality, 15(4), 374-380. http://dx.doi.org/10.1108/09604520510606844

Jalees, T. (2005). Marketing of Islamic Financial Products. Seminar. Karachi Institute of Economic and Technology, Karachi. June.

Jasimuddin, S. (2001). Saudi Arabian Banks on the Web. Journal of Internet Banking and Commerce. Retrieved from www.arraydev.com/commerce/jibc/0103_02htm

Jun, M., \& Cai, S. (2001). The Key Determinants of Internet Banking Service Quality: A Content Analysis. International Journal of Bank Marketing, 19(7), 276-291. http://dx.doi.org/10.1108/02652320110409825

Kahf, M. (2002). Strategic Trend in the Islamic Banking Finance Movement. Paper presented at Harvard forum on Islamic Finance and Banking. Harvard University, Cambridge, Boston.

Kahf, M. (2004). Success Factors of Islamic Banks. Brunei Symposium on Islamic Banking and Finance. Brunei. January.

Kahf, M., Ahmed, A., \& Homoud, S. (1998). Islamic Banking Development an Alternative Banking Concept. Islamic Research Training Institute (IRTI), Saudi Arabia.

Kim, K., \& Prabhakar, B. (2004). Initial Trust as a Determinant of the Adoption of Internet Banking. Database for Advances in Information Systems, Spring. Retrieved from http://mri.inha.ac.kr/article/8-1/banking\%5D.PDF

Maran, M., Jing. C. W., Gie. L. P., Mun. L. P., \& Ping, T. Y. (2010). Islamic Banking: Selection Criteria and Implications. Global Journal of Human Social Science, 10(4), 57.

Mathews, O. (2005). How the West Came To Run Islamic Banks. Newsweek [New York] October 31.

Metawa, S., \& AlMossawi, M. (1998). Banking Behaviour of Islamic Bank Customers: Perspectives and Implications. International Journal of Bank Marketing, 16(7), 299-313. http://dx.doi.org/10.1108/02652329810246028 
Mokhlis, S. (2009). Determinants of Choice Criteria in Malaysia's Retail Banking: An Analysis of Gender-Based Choice Decisions. European Journal of Economics, Finance and Administrative Sciences, 16.

Obaidullah, M. (2005). Islamic Financial Services. King Abdul Aziz University. Islamic Economics Research, $103-112$.

Parker, M. (2002), Battle of Islamic Credit Cards to Hot up. Arab News [Saudi Arabia] October 7.

Rice, G., \& AlMossawi, M. (2003). The Implications of Islam for Advertising Messages: The Middle Eastern Context. Journal of Euro Marketing, 11(3), 71-96. http://dx.doi.org/10.1300/J037v11n03_05

Rosly, S. (2003). The Role of the Fatwa in Islamic Finance. Investor's Digest 16 January. Retrieved from www.lexisnexis.com

Rosly, S. A., \& Abu Bakar, M. A. (2003). Performance of Islamic and Mainstream Banks in Malaysia. $\begin{array}{lllll}\text { International Journal of Social } & \text { Economics, } & 30(12), & 1249-1265 .\end{array}$ http://dx.doi.org/10.1108/03068290310500652

Rotchanakitumnuai, S., \& Mark, S. (2003). Barriers to Internet Banking Adoption: A Qualitative Study among Corporate Customers in Thailand. International Journal of Bank Marketing, 21(6/7), 312-323. http://dx.doi.org/10.1108/02652320310498465

Saeed, A. (1996). Islamic Banking and Interest: A Study of the Prohibition of Ribā in Islam and its Contemporary Interpretation. Netherlands, Leiden: Brill.

Sulaiman, A, Hee, C., \& Wee, A. (2005). Prospects and Challenges of e-Banking in Malaysia. The Electronic Journal of Information Systems in Developing Countries (EJISDC), 22.

Tahir, S. (2003). Current Issues in the Practice of Islamic Banking. Paper presented at course on Islamic Banking and Finance, Tehran, Iran.

Tahir, S. (2003). Islamic Banking and Finance. Lecture. Central Bank of the Islamic Republic of Iran and Islamic Research \& Training Institute. Saudi Arabia, Iran, March 2-6.

Tanjung, H. (2005). Five Star Formulas in Developing Islamic Banking: A Case study from Indonesia. Seminar arranged by International Islamic University Islamabad.

Usmani, T. (2002). An Introduction to Islamic Finance. Hague, Kluwer Law International.

Wang, Y., Hing, L., \& Hui, Y. (2003). The Antecedents of Service Quality and Product Quality and their Influences on Bank Reputation: Evidence from the Banking Industry in China. Managing Service Quality, 13(1), 72-83. http://dx.doi.org/10.1108/09604520310456726

Warde, I. (2000). Islamic Finance in the Global Economy. Edinburgh: Edinburgh University Press. http://dx.doi.org/10.3366/edinburgh/9780748612161.001.0001

Wilson, R. (2005). Parallels Between Islamic and Ethical Banking. Review of Islamic Economics, 10(18).

Wilson, R. (2005). The Growth of Islamic Banking and Product Development among Islamic Retail Banks. In J. Sohail (Ed.), Islamic Retail Banking and Finance: Global Challenges and Opportunities. London: Euromoney.

Wilson, R. (2005). The Politics of Islamic Finance. Retrieved from www.futureislam.com/20050501/insight/Rodney_Wilson/The_Politics_of_Islamic_Finance.asp53k

Yakcop, N. (2002). The Malaysian Strategy for Islamic Financial Market Development. Conference. International Islamic Capital Market, Kuala Lumpur.

Zaharuddin, A. (2006). Critical Issue in Qardhul Hasan. Business Times [Malaysia] September 20. Retrieved from www.rhbislamicbank.com.my

Zaharuddin, A. (2006). Sharīah Compliant paid-up Capital. Business Times [Malaysia] August 16. Retrieved from www.rhbislamicbank.com.my

Zaman, R., \& Movassaghi, H. (2002). Interest-free Islamic Banking: Ideas and Reality. International Journal of Finance, 14(4), 2428-2442. 


\section{Copyrights}

Copyright for this article is retained by the author(s), with first publication rights granted to the journal.

This is an open-access article distributed under the terms and conditions of the Creative Commons Attribution license (http://creativecommons.org/licenses/by/3.0/). 